\title{
Influence of Sacco Lending Rates on Dividend Payout Among DT Saccos in Kenya
}

\author{
Solomon Munyoki Kathuo*, Oluoch Oluoch, Agnes Njeru \\ Department of Economics and Finance, Jomo Kenyatta University of Agriculture and Technology, Nairobi, Kenya \\ Email address: \\ skathuo@yahoo.com (S. M. Kathuo), josephat.oluoch@jkuat.ac.ke (O. Oluoch), agnes3198@gmail.com (A. Njeru) \\ ${ }^{*}$ Corresponding author
}

\section{To cite this article:}

Solomon Munyoki Kathuo, Oluoch Oluoch, Agnes Njeru. Influence of Sacco Lending Rates on Dividend Payout Among DT Saccos in Kenya. International Journal of Finance and Banking Research. Vol. 6, No. 5, 2020, pp. 96-101. doi: 10.11648/j.ijfbr.20200605.12

Received: September 15, 2020; Accepted: October 22, 2020; Published: October 30, 2020

\begin{abstract}
This study explored the influence of sacco lending rates on dividend payout among saccos in Kenya. The study was motivated by inconsistency in the ability of Saccos to live up to their promise of paying dividends to members. There are variabilities in dividend payout based on different sacco sectors. Saccos pay dividends on a different percentage from the previous year. Different saccos have varying rates of interest charged on loans lend to members. The present study targeted all registered DTSSaccos in Kenya ( $\mathrm{n}=179)$ over an eight-year period (2012-2019). The study used panel data. Descriptive results showed that Sacco Lending interest rates which reflect the capacity of saccos to generate income, which they could distribute as dividends were on a downward trend, between 2012 and 2019 and large scale saccos had highest rates. Indeed, small saccos use dividends as a business strategy to retain and attract new members, thereby augment their capital. The findings from this study are useful to the board of directors and management team of companies in deciding an appropriate lending rate for the company. The results are also useful to shareholders in making investment decisions. The study extends empirical evidence on dividend policy determinants which are currently reported to be inconclusive. In addition, the study fills the lacuna in the existing literature by focusing on the issue of dividend policy determinants in the context of an emerging sector, namely saccos.
\end{abstract}

Keywords: Dividend Payout, Sacco Size, Lending Rates, Loans, Investment Decisions

\section{Introduction}

Deposit taking Saccos are known to play a vital role in growing savings and channeling credit. It can be argued that both in financial liquidity and membership, the cooperative movement in Kenya is the strongest in Africa, with about 5 million members [1]. The country's Sacco movement membership is valued over Kenyan shillings one trillion, and it is rated among the best in Africa [2]. The co-operative movement contributes over 30 percent of the country's national savings [3]. DT-saccos contribute over 61 percent of the total savings mobilized and over 68 percent of loans advanced by Saccos in Africa.

Many Kenyans have been relying on Savings and Credit Cooperative Societies (Saccos) to finance their socioeconomic obligation [4]. Deposit-taking Saccos are core to the cooperative movement. They control $78 \%$ of the total assets and deposits Sacco sub-sector and command $82 \%$ of the sector's membership [5]. They contribute $43 \%$ of Kenya's gross domestic product, and they are instrumental in financial inclusion and resource mobilization [6]. The DT-Saccos support the cooperative sub-sector with a consistent Compounded Annual Growth Rates (CAGR) of $11.30 \%$ in assets, $10 \%$ in deposits, $11.52 \%$ in loans and $16.96 \%$ in equity capital [7]. Saccos will continue to play a significant role in Kenyan financial inclusion agenda given their widespreasd networks throughout the country as well as competitive products and pricing.

Deposit-taking savings and credit cooperative societies (DT-Saccos) are vital in growing savings and channeling credit, a key pillar in mobilizing savings and investments under the Kenya Vision 2030 [8]. Saccos operating in the country are classified into five (5) main categories derived from the original common bond that defined the qualification of their membership, that is, government-based, teacherbased Saccos, farmer-based Saccos, private institutions, and 
community-based Saccos [9]. Saccos are a source of employment and provide revenue to the government in the form of taxes. Existing records indicate that Saccos in Kenya employ more than 500,000 Kenyans directly and 1.5 million indirectly [2]. Saccos form an important part of investment plans for many working-class and even self-employed citizens in Kenya. Many people join Saccos intending to accumulate savings, which entitles them to loans [2].

The Sacco Regulations of 2010 require Saccos to formulate a dividend policy considering Institutional Capital Adequacy (ICA), liquidity position, investment prospects, and earnings stability and growth prospects. The regulations allow Saccos to declare dividends only when in sound liquidity situations: Saccos should retain $15 \%$ of their savings deposits and short-term liabilities in liquid assets. For Saccos to meet statutory capital adequacy requirements, they may opt to adopt Dividend Reinvestment Plans (DRIPS) rather than cash dividend payment plans. Under DRIPs, shareholders will have their dividends automatically reinvested in additional shares. Although the emergence of SASRA regulations for all Saccos in 2010 changed the dynamics in the Sacco industry, the dividend practices of Saccos are unsatisfactory. Half of 179 registered deposittaking Saccos risked being stopped from paying dividends due to low levels of capital [10]. Deposit-taking Saccos suffered from a weak capital base that leads to low business volumes [10]. Despite the importance of the sub-sector, not much is known about the contexts and dynamics that shape how management treats dividends.

\section{Literature Review}

This paper adopts the agency cost theory [11]. The agency theory is a dominant theory on dividend payout. The agency cost theory suggests that dividend payout is determined by agency costs arising from the divergence of ownership and control [12]. Managers can undertake activities that stakeholders may deem costly, such as in making undue investments or earning high compensations [13]. Managers who should promote the interests of shareholders could use these resources to benefit themselves. Shareholders need to ensure that managers deploy excess cash to benefit shareholders. The desire to generate extra cash may push the managers to increase the lending interest rates of the saccos The cost of doing so has been called agency cost. If managers are driven to deploy the excess cash as dividends, this limits how the pool of funds they would have available to use to benefit themselves, rather than shareholders. This theory can be used to explain why Saccos borrow money to pay for dividends.

If a firm goes into financial decline or becomes unprofitable, managers will risk losing financially, a reality that would make them eschew risky investments [14]. For such managers, paying dividends to shareholders would diminish agency costs and reduce the likelihood of managers compensating themselves or investing in sub-optimal investments. Furthermore, when firms pay large dividends, they may be forced to seek external funds to do so, a step that would leave them under the scrutiny of players in the capital market [15].

Lending rates are the chief means by which Saccos accumulate surpluses to use to invest in assets or distribute in assets [10]. Lenders pay interest on loans, which are typically contingent on the value of commercial rates. Saccos make money by advancing loans at rates lower than rates charged by commercial banks. The compensation is the interest rate expressed as a rate percent per annum [10]. The Sacco lending interest rate for this study was the average prevailing emergency loan rate and other loan rates during the 8 years under the study.

Loans acquired to be put in long term capital investments are usually repaid in a series of monthly, semi-annual, and annual repayments. The amount to be paid is usually obtained using various ways: equal total payments per period (amortization), equal payments over a specified time with a balloon payment due at the end to repay the balance and equal principal payments per period. When the first method is used, the payment is inclusive of accrued interest on the unpaid balance together with some principal. The second way puts into consideration the accrued interest on the unpaid balance plus an equal amount of principal and lastly, the balloon method is meant to reduce the payment period [16]. Interest can be categorized as either short-term or long term. Long term loans have interest rates that seem to be constant within the repayment period while the short-term loans keep on changing from time to time.

The potential impact of interest rates on dividend payout has been a great concern for policymakers in various financial institutions and Saccos. The earnings of DTS and other financial institutions are greatly affected by uncertain changes in interest rates. Therefore, interest risk comes as a result of exposing the financial institutions' profitability to volatile interest rates. Hence DT-Saccos have a great challenge since they provide financial services to the poor and take care of their costs while aiming to avoid bankruptcy [17]. The firm's financial performance is highly influenced by risk and growth. The market value is conditioned with the company's results; therefore, the company market value can be changed by the level of risk exposure [18].

Generally, interest rates for long-term loans tend to be lower as compared to shorter loans which are slightly higher. Traditional finance theory puts it clear that as the loan size expands interest rate tends to rise to accommodate the increased risks associated with the loan. On the other hand, interest rates in Saccos are well explained by the characteristics of the borrower. Interest rates are a major concern to both lenders and borrowers in any given financial institution. Increased interest rates in financial institutions result in reduced customer borrowing and loan repayment capacity leading to an increased number of loan defaulters [19].

The potential impact of interest rates on dividend payout has been a great concern for policymakers in various financial institutions and Saccos. The earnings of DTS and 
other financial institutions are greatly affected by uncertain changes in interest rates. Therefore, interest risk comes as a result of exposing the financial institutions' profitability to volatile interest rates. Hence DT-Saccos have a great challenge since they provide financial services to the poor and take care of their costs while aiming to avoid bankruptcy [17]. The firm's financial performance is highly influenced by risk and growth. The market value is conditioned with the company's results; therefore, the company market value can be changed by the level of risk exposure [18].

\section{Methodology}

The present study explored the causal relationship or mechanism of dividend payout, and this involved the testing of several hypotheses. In both cases, quantitative forms of analysis were used, and this allowed the researchers to determine to predict and explain the phenomenon of dividend payout.

The philosophy allowed the use of a quantitative research method in this study. The quantitative method emphasizes on quantifying data and establishing causal relationships [20] Furthermore, quantitative methods involve gathering and analyzing information using mathematical methods, which are powerful technologies in understanding causal mechanisms [21].

Secondary data used in the study was obtained from Sacco societies' regulatory authority SASRA. This data had not been produced for the sole purpose of this study and as such is categorized as secondary data. The information utilized relating to the determinants of dividend payout among deposit-taking Saccos in Kenya were sourced from the annual accounts and annual filed reports by DT-Saccos for the period 2012-2019.

A list of all registered deposit-taking Saccos in operating in Kenya during the period 2012-2019 kept by SASRA both as a requirement by the Saccos Act and for public awareness constituted the sampling frame for this study.
The target population for this study comprised of the 179 DTS operating in Kenya as at 31st December 2019. The study employed a census study. The advantage of census is that it assures highest accuracy and concrete description of a phenomenon without any element of bias as all the elements are included [22].

The current study employed a panel data regression analysis. This is because the data set consists of observations of multiple variables over multiple periods. Panel data combines time-series and cross-sectional data. It allowed the researcher the flexibility in modeling differences in behavior across individual deposit-taking Saccos. It was appropriate for the study because of its ability in considering heterogeneity problems or individual effects in crosssectional data and in giving more informative data. Both descriptive and inferential statistics were used to analyze the quantitative data. Descriptive statistics describe and summarize the data in a meaningful way using charts, tables, and bars while inferential statistics conclude the analyzed data thus helping in the making of inferences. Descriptive statistics described the mean frequency counts and standard deviation. Pearson's correlation coefficient examined the relations between the variables under study. Panel regression scrutinized the results of the inner correlation of the variable and described the amount of variance. Predictions based on the results of the analysis were made and the results generalized on the population of the study.

\section{Results and Discussions}

Sacco lending interest rate was determined by considering both Sacco interest charged on emergency loans and interest charged on other loans over the the panel period. This section examines the descriptive statistics for Sacco lending rates. Consequently, it reports the findings of panel modeling of Sacco lending rates in relation to dividend payout. The results are presented in table 1 .

Table 1. Descriptive statistics of sacco lending interest rates.

\begin{tabular}{llll}
\hline Mean & Median & Minimum & Maximum \\
\hline 11.327 & 11.497 & 3.2142 & 19.766 \\
Std. Dev. & C. V. & Skewness & Ex. kurtosis \\
3.8963 & 0.34398 & 0.036133 & -0.81787 \\
$5 \%$ Perc. & $95 \%$ Perc. & IQ range & Missing obs. \\
5.0434 & 17.990 & 6.1323 & 0 \\
\hline
\end{tabular}

Table 1 shows that the average Sacco lending rate was 11.3 \pm 3.86 . This means Sacco lending rates fell in the range $7 \%-16 \%$. The minimum Sacco lending rate was 3.21 and the higher rate at about $20 \%$. The interquartile range of 6.1 is likely the rate charged by Saccos as loans. With a skewness of 0.036 and kurtosis of -.81 the distribution of Sacco lending rates appears to be normally distributed. A major determinant of Sacco lending rates was commercial lending rates, which was molded by Central Bank lending rates. Commercial bank lending rates moderates the relationship between $\mathrm{CBK}$ rates and Sacco lending rates. As such, the rate of lending by commercial banks has an immediate effect on how much Saccos can borrow, and how much interest they charge. High interest rates, such as those in the $95^{\text {th }}$ percentile, exposes Saccos to defaults.

Figure 1 shows the disaggregation of sacco lending interest rates based on sacco size. 


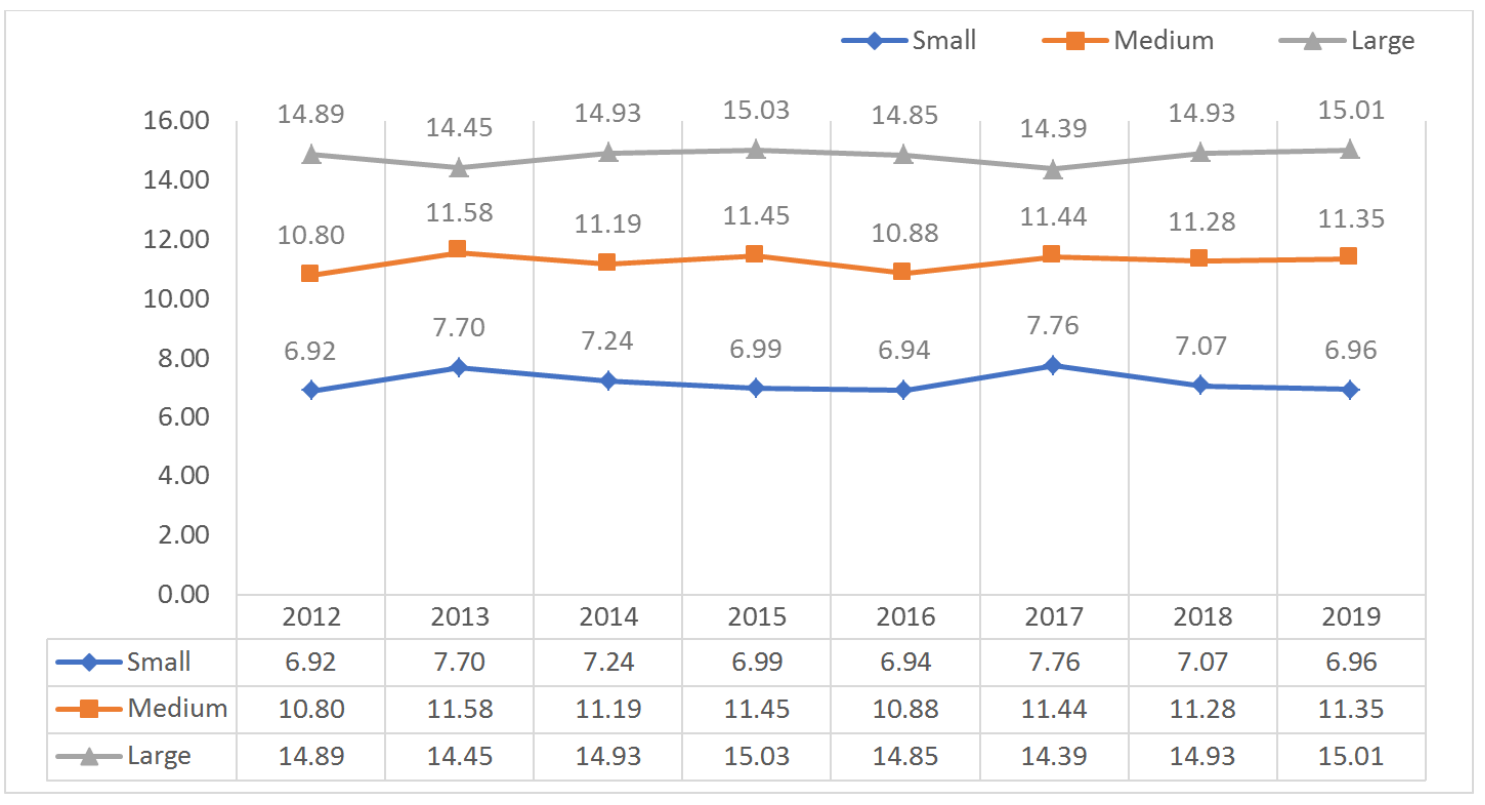

Figure 1. Depiction of Median Scores for average sacco lending rate 2012-2019 clustered about DT-Saccos based on sacco Size.

Figure 1 shows that lending rates were highest for large size Saccos, averaging $14.1 \%$. During the panel period, the lending rates fell by about 1 per cent. For medium sized Saccos, the average lending rates increased by $5 \%$ during the panel period. For small scale Saccos, the interest rate was $7.2 \%$, and this figure fell by 0.5 per cent over the panel period. Large scale DT-saccos seem to charge higher interest rates due to several factors, such as the perception that they are stable, less likely to fail, compared to small saccos, the ability to accumulate more deposits at lower deposit rates, all of which appear to drive the demand for loans from members leading to higher interest rates charged [23]. Besides, existing studies suggest that investors expect higher dividends from firms that charge higher interest rates, in this case, large scale Saccos [10]. According to the findings in this study, dividend payout was lower in large Saccos as against small Saccos, which had the lowest interest charged.

This paper hypothesized that Sacco lending rates and dividend payout do not have a significant relationship. The findings of panel modelling is depicted in table 2.

Table 2. Model Summary for the Relationship between Sacco Lending Rate and Dividend payout.

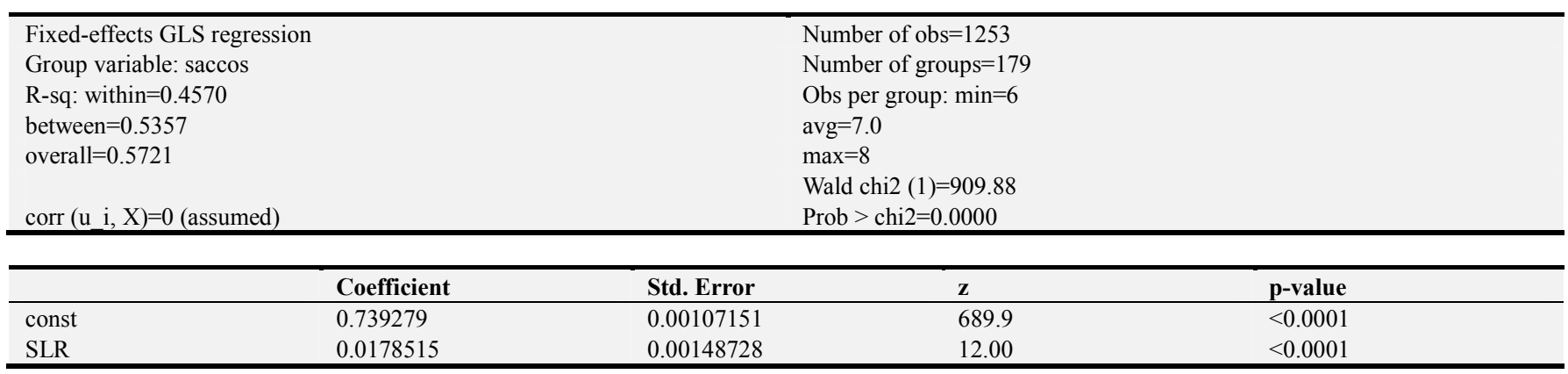

The study tested the following hypothesis.

$\mathrm{H}_{\mathrm{o}}$ : There is no significant relationship between Sacco lending interest rate and dividend pay-out among deposittaking saccos in Kenya.

$\mathrm{H}_{1}$ : There is a significant relationship between sacco lending interest rate and dividend pay-out among deposittaking saccos in Kenya. The study sought to establish the effect of the Sacco lending rate on dividend payout.

To determine the relationship, the model $y=\beta_{0}+\beta_{1} x_{3}+$ $\varepsilon$ was fitted. The model fitted was $\mathrm{y}=0.74+0.018$ SLR.

Since the $p$-value was $p=0.00$, the relationship between sacco lending rate and dividend payout was significant $(\mathrm{z}=12, \mathrm{p}=0.003)$. Accordingly, sacco lending rates can be deemed as a factor that helps explain variation in the dividend payout of deposit-taking saccos [24]. If so, examining the role of size as a moderating variable was tenable. In addition, the larger the size of sacco the more it can borrow funds from commercial banks, which gives it greater capacity to lend to members. Larger saccos are better placed to pay dividend in financial constraint compared to small ones, the reason being that they have large operational base, capital and assets to back any financial decision [23]. Larger saccos are better placed to generate resources from internal sources, making them depend less on lending rates that are influenced much by commercial bank lending rates.

Following both the Central Bank lending rates as well as commercial bank lending rates, sacco lending rates fell sharply between 2012-2019. This meant saccos had 
diminished spaces to generate revenue, more so because many saccos borrow from banks and lend to its members. As a result, saccos borrow heavily from commercial banks, funds that saccos use to lend to members. Importantly, despite the diminished capacity of saccos to generate local resources, which evidence on the trend of ROE shows, they sustained a liberal dividend policy between 2012 and 2019. What this means is that saccos use dividends as a strategy for attracting and retaining new members, whose primary motive is to earn dividends and access cheap loans.

The results were presented in table 3 .

Table 3. Model Summary for Causal Relationship between sacco lending rate and Dividend payout moderated by sacco Size.

\begin{tabular}{|c|c|c|c|}
\hline $\begin{array}{l}\text { Random-effects GLS regression } \\
\text { Group variable: saccos } \\
\text { R-sq: within }=0.5253 \\
\text { between }=0.6009 \\
\text { overall }=0.7001 \\
\text { corr }\left(u \_i, X\right)=0 \text { (assumed) }\end{array}$ & & $\begin{array}{l}\text { Number of obs }=1253 \\
\text { Number of groups }=179 \\
\text { Obs per group: } \min =6 \\
\text { avg }=7.0 \\
\max =8 \\
\text { Wald chi } 2(1)=27.83 \\
\text { Prob }>\text { chi } 2=0.0000\end{array}$ & \\
\hline Coefficient & Std. Error & $\bar{z}$ & p-value \\
\hline 0.827978 & 0.0132705 & 62.39 & $<0.0001$ \\
\hline 0.00224040 & 0.00112426 & 1.993 & 0.0463 \\
\hline 0.0303040 & 0.00820048 & 3.695 & 0.0002 \\
\hline
\end{tabular}

Model 1: Fixed-effects, using 1253 observations, included 179 cross-sectional units, Time-series length=7, Dependent variable: DR, Robust (HAC) standard errors

The overall $\mathrm{R}$ squared was 0.7001 , indicating that $70.01 \%$ of the variation in dividend payout was due sacco lending rate moderated by sacco size.

The finding suggests that size moderates the effect of sacco lending rate on dividend payout. In other words, sacco size is a factor in the amount of interest charged, which has effects on financial performance and dividend payout.

Saccos had diminished spaces to generate revenue, more so because the business model of Saccos is to charge interest rates lower than banks. As a result, Saccos borrow heavily from commercial banks, funds that Saccos use to lend to members. The study concurs with others studies which have found out that saccos will borrow heavily from banks to increase liquidity in order to pay dividends [24]. Importantly, despite the diminished capacity of Saccos to generate local resources, which the evidence on the trend of ROE shows, they sustained a liberal dividend policy between 2012 and 2019. What this means is that Saccos use dividends as a strategy for attracting and retaining new members, whose primary motive is to earn dividends and access cheap loans.

\section{Conclusions}

Lending rates reflect the capacity of Saccos to generate income, which they could distribute as dividends. Lending rates for Saccos were on a downward trend during the study period. Lending rates were highest for large scale Saccos, at $14 \%$ and lowest for medium scale ones, at 5\%. Small scale Saccos had an average lending rate, over the panel period, of 7.2 per cent. This trend was informed by a fall in both commercial lending rates as a well as CBK lending rates, a trend that should have diminished the dividends. If so, the capacity of Saccos to generate resources would be diminished over this period. Evidence from Sacco performance on return on equity would be helpful in explaining the motivation of Saccos to generate resources to be distributed as dividends. During the study period Sacco lending rates showed a significant downfall. This outcome would be expected to reduce the level of dividends paid out. Likewise, the financial performance of DT-saccos was on the decline. This meant Saccos had limited capacity and ability to generate resources locally. Even so, Saccos kept a liberal dividend policy. In this vein, the contextual factors at play, such as the need to keep existing members or attract fresh ones, could explain why even highly leveraged firms could keep a liberal dividend policy. It presents evidence that low short-term interest rates encourage Sacco risk-taking and reduce the credit risk of outstanding loans. However, credit risk becomes high at times when interest rates return to or rise above their average level after having been very low for a long period. This lowers dividend payout.

Although interest rates are not only the primary factors affecting dividend payout, Saccos should still be aware of their effects. Most members prefer to join Saccos that have lower lending interest rates. This implies that those Saccos that have high lending interest rates will over lower dividend payout because of decreasing number of membership.

\section{References}

[1] Sasra. (2014). The Sacco Societies Regulatory Authority Sacco Supervision Annual Report.

[2] Korir J. (2018). Effects of Dividend Policy on Financial Performance of Commercial Banks Listed at the Securities Exchange.

[3] Ndung'u, \& George M. (2010). Factors influencing Digital Divide In The Rural- And Semi- Urban Regions of Kenya: Case study of Juja Town and the Surrounding Areas.

[4] Ahmad. (2017). Determinants of dividend payout policy. An empirical study of banking sector of Pakistan. 
[5] SASRA, (2016). Sasra. (2013). SACCO Supervision Annual Report 2013, (Deposit Taking SACCOs)," SACCO Societies Regulatory Authority (SASRA), 2013.

[6] SASRA (2019). The Sacco Supervision Annual Report. Nairobi.

[7] Muthusi. (2014). University of Nairobi Institutional Repository.

[8] Musiega G, Alala B, Musiega D, Makomba C, \& EgessaR. (2013). Determinants of Dividend Payout Policy among non Financial Firms on The Nairobi Securities Exchange. International Journal of Scientific \& Technological Research, 2 (10).

[9] Eisenhardt. (1989). Agency theory: An assessment and Review Enow, ST and Issaca EBH. (2018). Factors that determine dividend payout: Evidence from the Financial sectors in South Africa. Journal of Banking and Finance Management, 1 (1), 48-53.

[10] Al-Malkawi H. (2007). Determinants of corporate dividend policy in Jordan. An Application of the Tobit Model. A journal of economics and adminstrative sciences, 44-70.

[11] Jensen M, \& MecklingW. (1976). Theory of Firm: managerial behaviour, agency cost and ownership structure. Journal of Financial Economics, 3 (4).

[12] Grinbalt M, \& Titman S. (1996). The Impact of Performance Based Fees on Pension Management. University of California.

[13] Shabibi, \& Ramesh. (2011). An Empirical Study on the Determinants of Dividend Policy in the UK. Journal of Finance and Economics Issue 80.

[14] Easterbrook F. H. (1984). Two Agency Costs Explanations of Dividends. Economic Review, 74, 650-659.
[15] Omokhudu O, \& Toluwa O. (2018). Agency cost and dividend policy in Nigerian Non-Financial Quoted Firms. International Journal of Academic Research In Business and Social Sciences, 8 (4), 325-350.

[16] Mwangi P, Mutiso A, \& Kabata D. (2018). Influence of Cshflow Liquidity on Dividend Payout Among Deposit Taking and Credit Cooperatives Societies (SACCos) in Kenya. International Journal of Finance and Accounting, 9 (20), 81-86.

[17] Appiah. (2011). The determinants of operational risk in US financial institutions.

[18] Edet B, Atairet E, \& Anoka F. (2014). Determinants of dividend payout of financial Institutions in Nigeria: A study of selected commercial banks. Research Journal of Finance and Accounting, 5 (7), 74-79.

[19] Sekaran, \& Bougie. (2010). Research methods for business: A skill-building approach 5 th ed.

[20] Greener. (2010). Improving health and well-being independently of GDP: Dividends of greener and prosocial economies.

[21] Blaikie N. (2010). Designing Social Research. Cambridge: Polity Press.

[22] Kothari C. (2004). Research Methodology: Methods and Techniques. New Delhi: New Age International Publishers.

[23] Were, \& Wambua. (2014). What factors drive interest rate spread of commercial banks? Empirical evidence from Kenya.

[24] Shibutse R, Kalunda E, \& Achoki G. (2019). Effect of Liquidity and Dividend Payout on Financial Performance of Deposit Taking Saccos in Kenya. Integrated Journal of Business and Economics, 297-312. 